\title{
Application of permutation frequency modulation signals manipulated with a constant weight code to increase the noise immunity of decameter radio communications
}

\author{
S. V. Dvornikova, Dr. Sc.,Tech., Professor, orcid.org/0000-0002-4889-0001, practicdsv@yandex.ru \\ A. A. Balykovb, Researcher, Post-Graduate Student, orcid.org/0000-0001-9311-1807 \\ S. S. Dvornikov', PhD, Tech., Head of a Laboratory, orcid.org/0000-0001-7426-6475 \\ a Saint-Petersburg State University of Aerospace Instrumentation, 67, B. Morskaia St., 190000, \\ Saint-Petersburg, Russian Federation \\ bS. M. Budenny Military Academy of Communication, 3, Tikhoretskii Pr., 194064, Saint-Petersburg, \\ Russian Federation
}

\begin{abstract}
Introduction: The operation of radio lines in the decameter range, as a rule, occurs in a complex interference environment, characterized by the presence of fast and slow fading. Therefore, one of the most relevant areas of research in this subject area is the development of new technical solutions aimed at improving the noise immunity of reception. Purpose: Development of signals with permuted frequency modulation that allow detecting single errors at the physical level by selecting combinations of subcarriers of each character in accordance with the alphabet of the code with a constant weight. Results: Theoretical aspects of formation of the permutation signals with frequency modulation, the choice manipulating code to select subcarriers within a signal symbol, presents an analytical approach for the derivation of the generalized expression evaluation of noise immunity of the developed signals of permutation modulation in a channel with variable parameters in incoherent processing, we obtained the estimation of the values of probability of bit error for new signals in comparison with the known results. Practical relevance: The developed signal with permuted frequency modulation is proposed to be used in decameter radio communication systems operating in a narrow frequency band in the ionospheric channel. Discussion: Further research is associated with optimization of decision-making procedures for demodulating the developed signals, as well as the search for effective ways to encode signals with permuted frequency modulation at the physical level, allowing to increase the data transfer rate while maintaining the noise immunity of reception.
\end{abstract}

Keywords - permutation frequency modulation, code manipulation with constant weight, decameter radio communication, noise immunity, probability of bit error, non-coherent signal processing, slow fading.

For citation: Dvornikov S. V., Balykov A. A., Dvornikov S. S. Application of permutation frequency modulation signals manipulated with a constant weight code to increase the noise immunity of decameter radio communications. Informatsionno-upravliaiushchie sistemy [Information and Control Systems], 2020, no. 6, pp. 30-36. doi:10.31799/1684-8853-2020-6-30-36

\section{Introduction}

Decameter radio systems operating in the ionospheric channel are characterized by slow fading. These fading are associated with the simultaneous reception of the direct and reflected beam. The main cause of fading is the passage of a reflected or scattered signal along several paths with different delay times [1].

In the case of slow fading, the waveform remains constant, but its power and phase change. This leads to a significant decrease in the quality of reception, although to a lesser extent than as a result of the effects of fast and selective fading, which significantly change the signal shape [2].

In practice, one of the main ways to eliminate intersymbol interference that occurs when radio waves pass in a fading ionospheric channel is to increase the chip duration. But this leads to a significant decrease in the bit rate, therefore, as a solution to this problem, it is proposed to use signals generated on the basis of permutation frequency modulation (PFM) [3].
The PFM methodology and various aspects of its application have been sufficiently studied [4-13]. Including the properties of PFM signals were investigated by Russian scientists $[4,8,11,13]$. So, in [11], the following features of PFM are highlighted, which made it possible to consider it as a promising direction for radio communication systems in the decameter range:

- each PFM signal symbol has the same energy;

- demodulation of messages is carried out at the stage of detecting signal symbols of the code word;

- the PFM implementation guarantees the same error probability when receiving any codewords from the allowed alphabet.

It is important to note that PFM, with relatively simple signal processing algorithms, provides a sufficiently high transmission rate while maintaining acceptable noise immunity.

Taking these circumstances into account, this article presents the results of a study of the noise immunity of signals developed in [4], with their incoherent processing in a channel with variable parameters. The peculiarity of the developed PFM signals 
is that in them the choice of the current combination of subcarriers for each symbol is carried out in accordance with the alphabet determined by the code with constant weight, which makes it possible to detect single errors already at the physical level [8].

\section{Theoretical aspects of the formation of signals of permutation frequency modulation for radio communication systems in the decameter range}

In general, PFM signals can be viewed as a kind of Multiple Frequency Shift Keying (FM- $m$ ), where $m$ is the number of frequency positions for subcarriers.

The synthesis of PFM- $m / k$ signals can be carried out in accordance with the expression

$$
s_{\mathrm{PFM}-m / k}(t)=\frac{1}{N} \sum_{i=1}^{m} s_{i}(t) \otimes \mathbf{A}
$$

Here $s_{i}(t)$ are harmonics per $m$ subcarriers within the signal bandwidth; $\mathbf{A}$ is a vector of dimension $m$, the elements of which are " 0 " and " 1 ", and " 1 " indicates the active subchannel on the duration of the signal element (the number of units of vector $\mathbf{A}$ is determined by the value $k$ ), the number " 0 " - on the passive one.

In contrast to multi-position frequency shift keying, in which each signal symbol is determined by the position of only one subcarrier in a given frequency band, in PFM it is formed by choosing a certain combination of several subcarriers, total number $k$, where $k \in[1 ;\lfloor m / 2\rfloor]$ (here $\lfloor *\rfloor$ is the integer division operation). The use of permutation modulation can significantly expand the alphabet, and thereby increase the transmission rate. So, if the signals of multi-frequency modulation FM- $m$ information bit rate $R_{b}$ is related to the symbol rate $R_{s}$ by the following relationship [2]:

$$
R_{b}=R_{s} \times\left\lfloor\log _{2} m\right\rfloor,
$$

then for PFM- $m / k$ signals the specified connection will be as follows:

$$
R_{b}=R_{s} \times\left\lfloor\log _{2} C_{m}^{k}\right\rfloor=R_{s} \times\left\lfloor\log _{2} \frac{m !}{k !(m-k) !}\right\rfloor .
$$

To clarify the essence of this feature, in Fig. 1 is a three-dimensional diagram showing the dependence of the distribution of bits per symbol $B(m)$, on the number of frequency positions $m$, on the duration of the signal element for a different value of $k$, which determines the number of involved subcarriers (active subchannels), in accordance with the expression

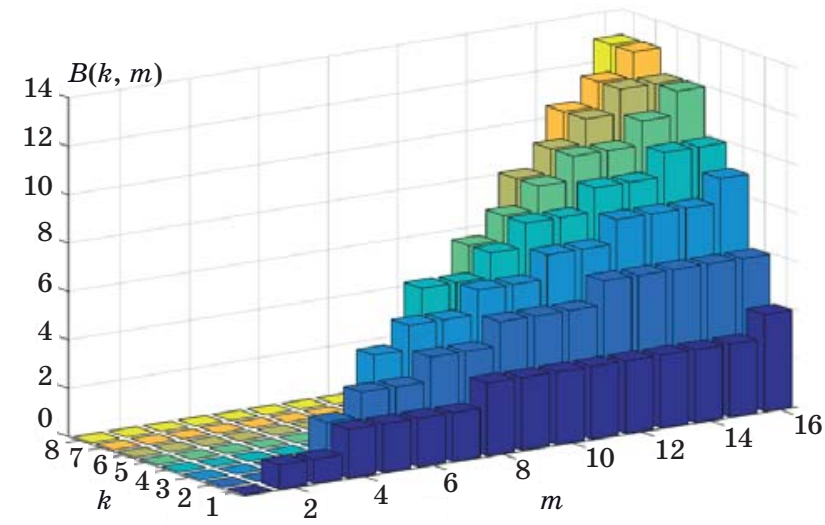

Fig. 1. Dependence of dimension symbol on the number of frequency positions $m$, for a different number of active subcarriers $k$

$$
B(m)=\left\lfloor\log _{2} \frac{m !}{k !(m-k) !}\right\rfloor
$$

The analysis presented in Fig. 1 of the result shows that in relation to decameter communication channels, for which, as a rule, signal structures with a dimension of more than 16 are not used [14], a significant gain occurs in the case when the parameter $k$ in its value approaches $m$. It should be borne in mind that an increase in $k$ leads to a significant decrease in the energy falling on each of the subcarriers. This ultimately degrades the noise immunity of transmissions based on PFM signals $[8,13]$.

Therefore, a compromise is needed between the ratio of $k$ and $m$.

Thus, the analysis of the ALE $2 \mathrm{G}$ standard (automatic installation of the 2nd generation channel) [15] shows that for radio communication systems in the decameter range, the choice of eight-position frequency-shift keying signals (FM-8 signals) with a bandwidth of about $2 \mathrm{kHz}$ is justified. This signal provides a symbol rate of 125 baud. The indicated value is confirmed by the long-term practice of message transmission via the ionospheric channel (channel with variable parameters). Therefore, when choosing the value of $m$ for transmission with PFM signals, it is advisable to focus on the frequency band determined by the symbol rate in the range from 100 to 250 baud.

The diagram obtained in the course of the study, shown in Fig. 1, clearly illustrates the obviousness of the choice with the total number of subchannels $m=8$, the parameter value $k=3$. The expediency of such a choice is due to the fact that in this case, each symbol of the PFM-7/3 signal will provide the transmission of five bits, with a slight decrease in energy indicators attributable to recalculation for each active subcarrier. 


\section{The choice of the manipulating code for the formation of signals PFM-7/3}

For efficient transmission of information, the choice of active subcarriers on the chip duration must be determined in accordance with a given alphabet. The capacity (size) of the alphabet will be determined by the values $m=8$ and $k=3$, in accordance with the following combination formula [8]

$$
C_{m}^{k}=\frac{m !}{k !(m-k) !}
$$

According to formula (5), for the indicated values of $m$ and $k$, the capacity of the alphabet will be 35 elements. Moreover, for a seven-digit symbol, the number of elements of the alphabet is $2^{7}=$ $=128$. The analysis of existing codes in [4] showed the advisability of choosing for the indicated combinations of the International Telegraph Alphabet (ITA) with a constant weight of the ITA-3. The choice of this code is due to its properties, which make it possible to detect an error in a code combination if the odd parity of the units contained in it is violated. Exceptions are situations that result in offset errors. The occurrence of these errors is associated with the mutual transition of the allowed " 0 " to " 1 " and vice versa, the allowed " 1 " to "0". Such errors lead to the combination allowed for the alphabet. But it should be borne in mind that the combination obtained in this case does not correspond to the combination transmitted by the received symbol.

Thus, the use of ITA-3 for coding subcarriers will allow, even before demodulation, to inform the recipient about the presence of an error in the received symbol, based on the results of evaluating the odd parity violation of active subchannels. This circumstance emphasizes the originality of the solution associated with the choice of the ITA-3 code for encoding the signal symbols PFM-7/3.

\section{Evaluation of the noise immunity of the PFM-7/3 signals in the channel with variable parameters with incoherent processing}

In [9], the following expression was proposed for calculating the error probability for PFM signals under the conditions of their incoherent demodulation:

$$
P_{\mathrm{PFM}}=\int_{0}^{\infty}\left[1-\left(1-\exp \left[\frac{z^{2} m}{2 \sigma^{2}}\right]^{m-k}\right)\right] \times
$$

$$
\times\left[\begin{array}{c}
\left.1-\operatorname{erf}\left(\left[z-\frac{u \sqrt{2}}{\sqrt{k}}\right] \sqrt{m} \sigma^{-1}\right)^{k-1} \times\right] \\
\times k \frac{\sqrt{m}}{\sqrt{2 \pi} \sigma} \exp \left[-\frac{\left[z-\frac{u \sqrt{2}}{\sqrt{k}}\right]^{2} m}{2 \sigma^{2}}\right]
\end{array}\right] \mathrm{d} z .
$$

Here $u$ is the root-mean-square voltage of the signal in the channel; $\sigma$ is the root-mean-square noise voltage in the channel; $z$ is the accepted implementation of the signal in noise.

It should be noted that expression (6) has a rather complex analytical representation for its interpretation and modeling, therefore, a different approach is proposed to substantiate the formula for evaluating the noise immunity of the PFM-7/3 signals with their incoherent processing. In particular, in Fig. 2 shows the spectra of the signals PFM-2/1 $\left|F_{\text {PFM-2/1 }}(f)\right|$ (frequency telegraphy) and PFM-7/3 $\left|F_{\text {PFM-7/3 }}(f)\right|$.

With regard to orthogonal systems with an active pause, with incoherent reception in a channel with variable parameters, the probability of a symbolic error is determined using the expression:

$$
P_{s}=\sum_{n=1}^{m-1}(-1)^{n+1} C_{m-1}^{n} \frac{1}{n h^{2}+n+1} .
$$

Here $h^{2}$ is the average ratio of the signal energy to the power spectral density of the noise (interference).

Next, we recalculate the probability of a symbolic error into a bit error

$$
P_{b}=\frac{m / 2}{m-1} P_{s}
$$

Now, in the interest of obtaining an expression for estimating the potential noise immunity of a signal with an orthogonal permutable frequency modulation of the PFM- $m / k$, formed by coding active subcarriers with a constant weight code at the physical level, it is necessary to consider the independent reception of $k$ active tones on the signal chip duration. In this case, it is necessary to take into account that the energy of each of the tone oscillations at its own sub-frequency will decrease $k$ times. Moreover, the signal symbol will be correctly identified only if each of the tonal fluctuations is reliably received. This is possible only if the condition

$$
h^{2} \rightarrow \frac{h^{2}}{k}
$$




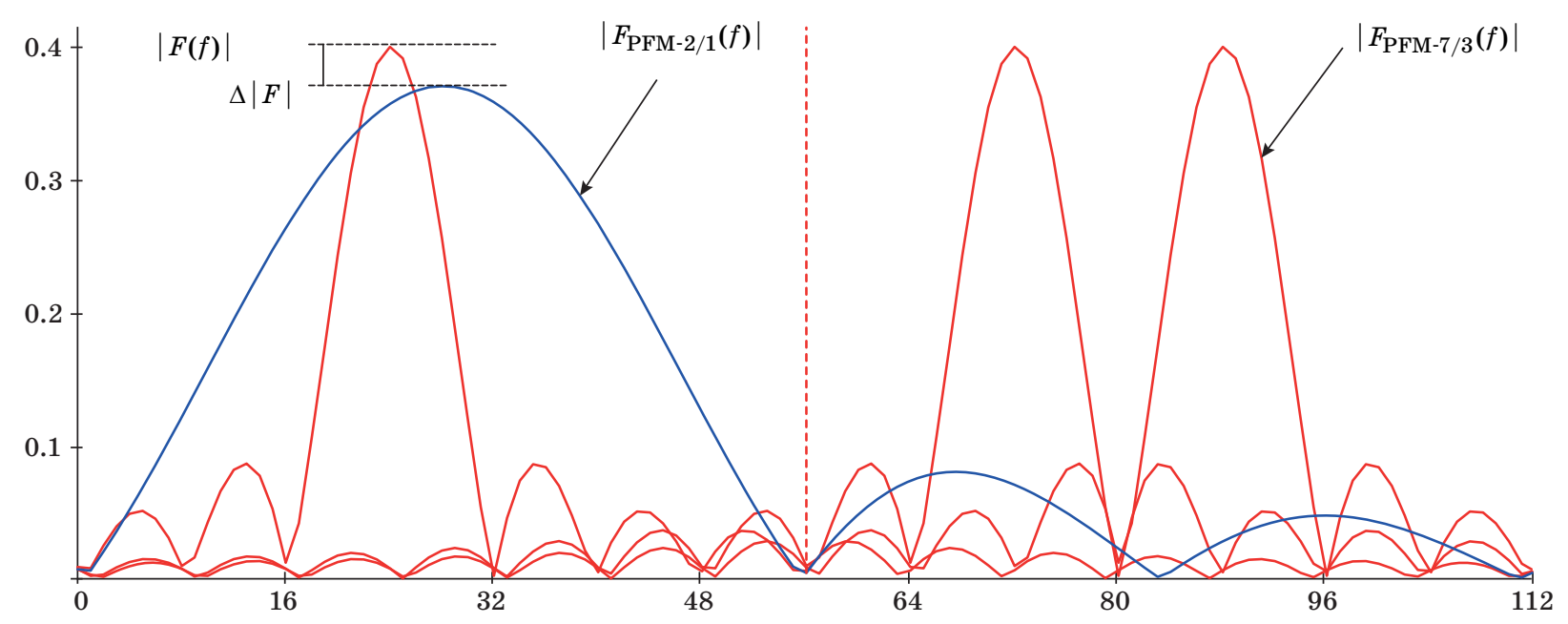

Fig. 2. Functions of envelope spectra of signals of transmissions of permutation manipulation on symbol duration within the limited channel

Condition (9) can be interpreted in such a way that correct reception is possible only when the average level of each of the $k$ active tonal oscillations exceeds the average value of the signal level together with interference within the passive subchannels [16], for which, according to formula (1), the element of vector A is "0". For further derivation of the required expression, we turn to the concept of the probability of error-free reception, which is the inverse for $P_{s}$ :

$$
P_{0}=1-P_{s}
$$

Taking into account the assumptions made, the expression for calculating the probability of symbolic error for a channel with variable parameters will be as follows:

$$
P_{s}=1-\left[1-\sum_{n=1}^{m-1}(-1)^{n+1} C_{m-1}^{n} \frac{1}{\frac{n h^{2}}{k}+n+1}\right]^{k} .
$$

However, formula (11) does not take into account the fact that if the first tone waveform can be received on any of the $m$ possible subchannels in the passband, then for the second tone waveform on the duration of the same symbol, only $m-1$ subchannels in within the same bandwidth, etc.

Taking into account the additions made, we transform expression (11) to the form:

$$
P_{s}=1-\prod_{s=1}^{k}\left[1-\sum_{n=1}^{m-s}(-1)^{n+1} C_{m-s}^{n} \frac{1}{\frac{n h^{2}}{k}+n+1}\right] .
$$

Now, to recalculate the probability of a symbolic error into a bit error, consider the formation of allowed combinations when encoding with a code with a constant weight $(k, m)$. Note that a binary number will be associated with each allowed combination, and the number of such binary numbers $L$ will not exceed the size of the allowed alphabet. Therefore, the number of used alphabet combinations is calculated by the formula

$$
L=2^{\left\lfloor\log _{2} C_{m}^{k}\right\rfloor} .
$$

And then, taking into account formulas (12) and (13), we obtain the resulting expression for calculating the bit error probability of orthogonal signals with permutational frequency modulation, encoded with a constant weight code at the physical layer. The expression is valid for the conditions of incoherent reception in a channel with variable parameters (ionospheric channel in the decameter range):

$$
\begin{gathered}
P_{s}=\frac{L / 2}{L-1} \times \\
\times\left(1-\prod_{s=1}^{k}\left[1-\sum_{n=1}^{m-s}(-1)^{n+1} C_{m-s}^{n} \frac{1}{\frac{n h^{2}}{k}+n+1}\right]\right) .
\end{gathered}
$$

According to expression (14), the decision on the transmitted symbol is made at the $k$ maximum levels in the passbands of the corresponding tones. That is, in the received signal symbol, the position of $k$ active subcarriers will correspond to the allowed constant weight code combination, which is $k$. This will allow implementing the property of the code to detect er- 

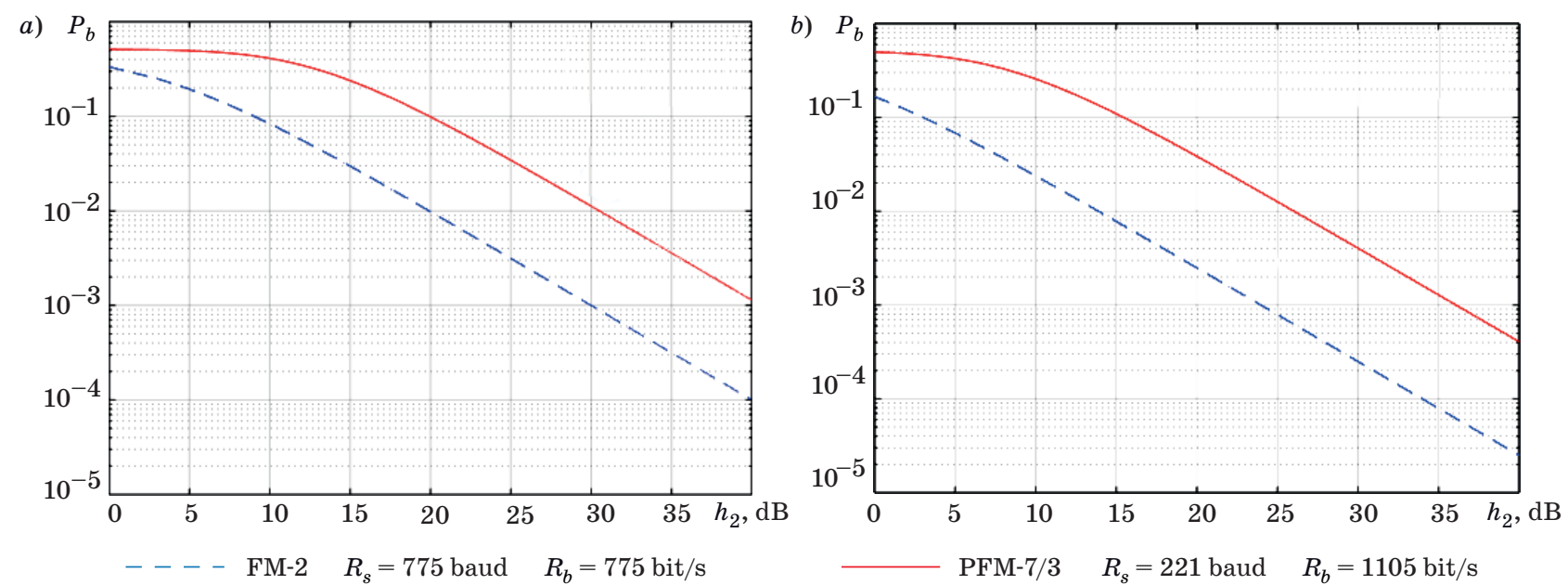

- Fig. 3. Dependence of the bit error probability on the ratio of bit energy to noise density ( $a$ ) and of signal power to noise power $(b)$ for FM-2 (PFM-2/1) and PFM-7/3 signals in a channel with variable parameters for incoherent reception

rors at the stage of signal reception. Only the resulting offset errors will not be detected.

In Figures 3, $a$ and $b$ show graphs of the dependence of the bit error probability for signals with permutable frequency modulation.

Analysis of the results presented in the form of graphs in Fig. 3 allows us to conclude that the use of signals PFM-7/3 leads to a decrease in the symbol rate, but at the same time the bit rate increases to $\mathbf{1 1 0 5}$ bits per second. But precisely due to the decrease in the symbol rate from 775 to 221 baud compared to FM-2 signals in the $3100 \mathrm{~Hz}$ frequency band, the influence of intersymbol interference on the transmitted signal will no longer be so significant. The price for this is a loss in energy efficiency (up to 10-12 dB).

However, it should be borne in mind that if the achievement of energy performance in decameter radio communication systems can be achieved by selecting the optimal operating frequencies and increasing the power of the transmitters, then it is almost impossible to avoid problems with intersymbol interference, which leads to a sharp increase in the probability of error above the permissible at the symbol rate of 775 baud.

\section{Conclusion}

The physical simplicity of the formation and processing of signals of permutable frequency modulation makes them very interesting for practical use in radio communication systems of the decameter range.

In particular, the proposed PFM-7/3 signals, encoded by the ITA-3 code, make it possible to additionally detect symbolic errors at the physical level, which, according to the authors, will further increase the noise immunity of reception.
Another interesting aspect is seen in the application of correcting codes for subcarrier manipulation as well as wavelet signals.

The signals with permutational frequency modulation, formed on the basis of codes with constant weight, in a channel with variable parameters are inferior in noise immunity to signals of multi-position frequency modulation. This is due to the fact that the transmitter power is evenly distributed between the passbands of the active sub-frequencies in accordance with the given coding. But the loss in the energy aspect, in a sense, is compensated by the properties of higher spectral efficiency, which makes it possible to increase the number of bits per symbol.

In radio communication systems operating in ionospheric channels with multipath propagation, signals with permutational frequency modulation can serve as a good alternative to signals generated on the basis of technology with orthogonal frequency multiplexing of channels.

The authors associate further research with the search for optimal decision-making criteria when demodulating PFM signals.

\section{References}

1. Nguyen Minh Zhang. Metod $i$ algoritm prog nozirovaniya uglov prikhoda dekametrovykh radiovoln pri ikh rasprostranenii $v$ gorizontal'no - neodnorodnoy rasseivayushchey ionosphere. Dis. kand. techn. nauk [Method and algorithm for predicting the angles of arrival of decameter radio waves during their propagation in a horizontally inhomogeneous scattering ionosphere. PhD tech. sci. diss.]. Irkutsk, Irkutskij nacional'nyj issledovatel'skij tekhnicheskij universitet Publ., 2017. 23 p. (In Russian). 
2. Kandaurov N. A. Signal'no-kodovyye konstruktsii dlya nizkoenergeticheskikh shirokopolosnykh radioliniy dekametrovogo diapazona. Dis. kand. techn. nauk [Signal-code structures for low-energy broadband radio lines of the decameter range. $\mathrm{PhD}$ tech. sci. diss.]. Moscow, Moskovskij tekhnicheskij universitet svyazi i informatiki Publ., 2019. 23 p. (In Russian).

3. Naoki Ishikawa, Shinya Sugiura, and Lajos Hanzo. 50 years of permutation, spatial and index modulation: from classic $\mathrm{RF}$ to visible light communications and data storage. IEEE Communications Surveys \& Tutorials, 2018, vol. 20, iss. 3, pp. 1-32. doi:10.1109/ COMST.2018.2815642

4. Dvornikov S. V., Popov E. A., Balykov A. A., Dvornikov S. S. Interference stability of signals with transfer frequency modulation in channels with constant parameters when incorrect reception. Radioengineering, 2019, no. 12 (20), pp. 24-31 (In Russian). doi:10.18127/j00338486-201912(20)-04

5. Ishikawa N. Space-, time-, and frequency-domain permutation modulation designed for microwave and optical wireless communications. PhD dissertation, Tokyo University of Agriculture and Technology, 2017. Corpus ID: 67371011

6. Bian Y., Cheng X., Wen M., Yang L., Poor H. V., Jiao B. Differential spatial modulation. IEEE Transactions on Vehicular Technology, 2015, vol. 64, no. 7, pp. 3262-3268. doi:10.1109/TVT.2014.2348791

7. Ishikawa N., Rajashekar R., Sugiura S., Hanzo L. Generalized spatial modulation based Reduced-RFChain Millimeter-Wave communications. IEEE Transactions on Vehicular Technology, 2017, vol. 66, no. 1, pp. 879-883. doi:10.1109/TVT.2016.2555378

8. Dvornikov S. V., Ovchinnikov G. R., Balykov A. A. Programmed simulator of the ionospheric radio channel of the decameter range. Information and Space, 2019, no. 3, pp. 6-12 (In Russian).

9. Ishimura S., Kikuchi K. Multi-dimensional permutation-modulation format for coherent optical commu- nications. Optics Express, 2015, vol. 23, iss. 12, pp. 15587-15597. doi:10.1364/OE.23.015587

10. Sugiura S., Ishihara T., Nakao M. State-of-the-art design of index modulation in the space, time, and frequency domains: Benefits and fundamental limitations. IEEE Access, 2017, vol. 5, pp. 21774-21790. doi:10.1109/ACCESS.2017.2763978

11. Bykhovsky M. A. Noise immunity of signal reception during permutation modulation. T-Comm: Telecommunications and Transportation, 2015, vol. 9, no. 4, pp. 12-16. doi:10.36724

12. Ishimura S., and Kikuchi K. Multi-dimensional permutation modulation aiming at both high spectral efficiency and high power efficiency. Optical Fiber Communications Conference (OFC 2014), 2014, M3A.2. doi:10.1364/OFC.2014.M3A.2

13. Dvornikov S. V., Balykov A. A. Proposals for controlling the transmission rate and noise immunity of signals with permutable frequency modulation. T-Comm: Telecommunications and Transportation, 2020 , vol. 14 , no. 6 , pp. 20-26. doi:10.36724/20728735-2020-14-6-20-26

14. Shagarova A. A. Issledovaniye metodov i algoritmov povysheniya dostovernosti dannykh $v$ sisteme aviatsionnoy elektrosvyazi dekametrovogo diapazona. Dis. kand. techn. nauk [Research of methods and algorithms for increasing the reliability of data in the aviation telecommunication system of the decameter range. $\mathrm{PhD}$ tech. sci. diss.]. Ulyanovsk, Ul'yanovskij gosudarstvennyj tekhnicheskij universitet Publ., 2016. 16 p. (In Russian).

15. Fixed HF radio communication systems. Rep. ITU-R F.2061. Available at: https://www.itu.int/dms_pub/ itu-r/opb/rep/R-REP-F.2061-2006-PDF-R.pdf (accessed 30 August 2020).

16. Makoviy V. A. Numbering of permutation modulation channel symbols. Teoriya $i$ tekhnika radiosvyazi, 2009, no. 4, pp. 17-22 (In Russian).

удК 621.396

doi:10.31799/1684-8853-2020-6-30-36

Применение сигналов перестановочной частотной модуляции, манипулированных кодом с постоянным весом, для повышения помехоустойчивости радиосвязи декаметрового диапазона

С. В. Дворников ${ }^{\mathrm{a}}$, доктор техн. наук, профессор, orcid.org/0000-0002-4889-0001, practicdsv@yandex.ru

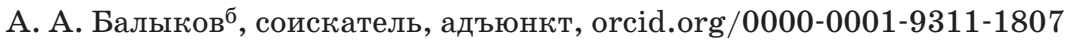

C. С. Дворников ${ }^{\sigma}$, канд. техн. наук, начальник лаборатории кафедры применения войск связи, orcid.org/00000001-7426-6475

аСанкт-Петербургский государственный университет аэрокосмического приборостроения, Б. Морская ул., 67, Санкт-Петербург, 190000, РФ

бВоенная академия связи им. Маршала Советского Союза С. М. Буденного, Тихорецкий пр., 3, Санкт-Петербург, 194064, РФ

Введение: работа радиолиний декаметрового диапазона, как правило, происходит в сложной помеховой обстановке, характеризующейся наличием быстрых и медленных замираний. Поэтому актуальным исследованием в данной предметной области является разработка новых технических решений, направленных на повышение помехоустойчивости приема. Цель: разработка сиг- 
налов с перестановочной частотной модуляцией, позволяющих на физическом уровне обнаруживать единичные ошибки за счет выбора сочетаний поднесущих каждого символа в соответствии с алфавитом кода с постоянным весом. Результаты: рассмотрены теоретические аспекты формирования сигналов с перестановочной частотной модуляцией; обоснован выбор манипулирующего кода для выбора поднесущих в пределах сигнального символа; представлен аналитический подход к выводу обобщенного выражения оценки помехоустойчивости разработанных сигналов перестановочной модуляции в канале с переменными параметрами при некогерентной обработке; приведены графики оценки значений вероятности битовой ошибки для новых сигналов в сравнении с известными результатами. Практическая значимость: разработанный сигнал с перестановочной частотной модуляцией предлагается использовать в системах декаметровой радиосвязи, работающих в узкой полосе частот в ионосферном канале. Обсуждение: дальнейшие исследования авторы связывают с оптимизацией процедур принятия решения при демодуляции разработанных сигналов, а также с поиском эффективных способов кодирования сигналов с перестановочной частотной модуляцией на физическом уровне, позволяющих повысить скорость передачи данных при сохранении помехоустойчивости приема.

Ключевые слова - перестановочная частотная модуляция, манипуляция кодом с постоянным весом, декаметровая радиосвязь, помехоустойчивость, вероятность битовой ошибки, некогерентная обработка сигналов, медленные замирания.

Для цитирования: Dvornikov S. V., Balykov A. A., Dvornikov S. S. Application of permutation frequency modulation signals manipulated with a constant weight code to increase the noise immunity of decameter radio communications. Инфорлационно управляющие системы, 2020, № 6, с. 30-36. doi:10.31799/1684-8853-2020-6-30-36

For citation: Dvornikov S. V., Balykov A. A., Dvornikov S. S. Application of permutation frequency modulation signals manipulated with a constant weight code to increase the noise immunity of decameter radio communications. Informatsionno-upravliaiushchie sistemy [Information and Control Systems], 2020, no. 6, pp. 30-36. doi:10.31799/1684-8853-2020-6-30-36

\section{УВАЖАЕМЫЕ АВТОРЫ!}

Научная электронная библиотека (НЭБ) продолжает работу по реализации проекта SCIENCE INDEX. После того как Вы зарегистрируетесь на сайте НЭБ (http://elibrary.ru/ defaultx.asp), будет создана Ваша личная страничка, содержание которой составят не только Ваши персональные данные, но и перечень всех Ваших печатных трудов, имеющихся в базе данных НЭБ, включая диссертации, патенты и тезисы к конференциям, а также сравнительные индексы цитирования: РИНЦ (Российский индекс научного цитирования), $\mathrm{h}$ (индекс Хирша) от Web of Science и h от Scopus. После создания базового варианта Вашей персональной страницы Вы получите код доступа, который позволит Вам редактировать информацию, помогая создавать максимально объективную картину Вашей научной активности и цитирования Ваших трудов. 